\title{
Intra-annual patterns of tracheid size in the Mediterranean tree Juniperus thurifera as an indicator of seasonal water stress
}

\author{
Lucía DeSoto, Marcelino De la Cruz, and Patrick Fonti
}

\begin{abstract}
Because climate can affect xylem cell anatomy, series of intra-annual cell anatomical features have the potential to retrospectively supply seasonal climatic information. In this study, we explored the ability to extract information about water stress conditions from tracheid features of the Mediterranean conifer Juniperus thurifera $\mathbf{L}$. Tracheidograms of four climatic years from two drought-sensitive sites in Spain were compared to evaluate whether it is possible to link intra-annual cell size patterns to seasonal climatic conditions. Results indicated site-specific anatomical adjustment such as smaller and thicker tracheids at the dryer site but also showed a strong climatic imprint on the intra-annual pattern of tracheid size. Site differences in cell size reflected expected structural adjustments against cavitation failures. Differences between intra-annual patterns, however, indicated a response to seasonal changes in water availability whereby cells formed under drought conditions were smaller and thicker, and vice versa. This relationship was more manifest and stable at the dryer site.
\end{abstract}

\begin{abstract}
Résumé : Étant donné que le climat peut influencer l'anatomie des cellules du xylème, il est possible que des séquences des caractéristiques anatomiques intra-annuelles des cellules puissent, rétrospectivement, fournir des informations climatiques saisonnières. Dans cette étude, nous avons exploré la capacité d'extraire de l'information au sujet des conditions de stress hydrique à partir des caractéristiques des trachéides du Juniperus thurifera $\mathbf{L}$., un conifère de la région méditerranéenne. Les trachéidogrammes de quatre années climatiques provenant de deux stations sujettes à la sécheresse en Espagne ont été comparés pour évaluer s'il est possible de relier le patron intra-annuel de la dimension des cellules et les conditions climatiques saisonnières. Les résultats ont montré qu'il y avait une adaptation anatomique spécifique à la station, telle que des trachéides plus petites et plus épaisses dans la station la plus sèche, mais qu'il y avait aussi une forte empreinte climatique dans le patron intra-annuel de la dimension des trachéides. Les différences entre les stations quant à la dimension des cellules reflétaient les adaptations structurales prévisibles pour prévenir les accidents dus à la cavitation. Cependant, les différences entre les patrons intra-annuels étaient dues à une réaction aux changements saisonniers dans la disponibilité en eau, à la suite de laquelle les cellules formées dans des conditions de sécheresse étaient plus petites et plus épaisses et vice-versa. Cette relation était plus évidente et stable dans la station la plus sèche.
\end{abstract}

[Traduit par la Rédaction]

\section{Introduction}

The wood anatomical structure of woody plants is mainly genetically determined and can therefore be used as a trait for taxonomic classification. However, intraspecific variability is also subject to environmental modification (Wimmer 2002; Schweingruber 2007). In fact, trees have to adjust their xylem structure to fit the ecological settings of their habitat and the seasonal and interannual climate variability (Fonti et al. (2010) and references therein). By performing these adjustments, the environmental conditions that occur during wood formation, i.e., the conditions affecting processes of cell division, differentiation, enlargement, and wall thickening, leave a permanent mark on cell anatomical characteristics (Denne and Dodd 1981), and thus, like other tree-ring proxies such as ring width or maximum latewood density, they can be assigned to a calendar year and used to indirectly reconstruct past environmental dynamics (Fritts 2001).

Recent analyses of interannual variability in the size of water-conducting cells (vessels in deciduous trees and tracheids in conifers) are demonstrating that these cells can carry subannual information that reflects changes in environmental conditions (for a review, see Fonti et al. 2010). Temperature has been observed to mainly affect physiological processes involved in wood formation such as synthesis and transport of hormones (e.g., Creber and Chaloner 1984; Uggla et al. 1998, 2001; Oribe et al. 2003). So, for example, it has been observed that previous fall and spring temperatures can affect

L. DeSoto.* Departamento de Ciencias Agroforestales, Área de Botánica, EUI Agrarias, Universidad de Valladolid, Los Pajaritos s/n, E42004 Soria, Spain.

M. De la Cruz. Departamento de Biología, E.U.I.T. Agrícola, Universidad Politécnica de Madrid, E-28040 Madrid, Spain.

P. Fonti. WSL Swiss Federal Research Institute, Landscape Dynamics, Zürcherstr. 111, CH-8903 Birmensdorf, Switzerland.

Corresponding author: Lucía DeSoto (e-mail: luciadesoto@gmail.com).

*Present address: Centre for Functional Ecology, Department of Life Sciences, University of Coimbra, 3001-455 Coimbra, Portugal. 
earlywood vessel size of the ring-porous Castanea sativa (Fonti et al. 2007) and that tracheid size (lumen diameter and wall thickness) is positively correlated with late spring and summer temperatures (in Pinus sylvestris (Antonova and Stasova 1993), Larix sibirica (Antonova and Stasova 1997), Picea mariana (Wang et al. 2002), and Larix cajanderi (Panyushkina et al. 2003)). In contrast, water availability seems to influence principally cell turgidity during cell expansion (e. g., Vysotskaya and Vaganov 1989; Gindl 2001). Experiments performed on tree saplings have indicated that water deficit reduces cell number and tracheid lumen diameter but increases cell wall thickness (Sheriff and Whitehead 1984; Abe and Nakai 1999; Abe et al. 2003; Rossi et al. 2009; Gallé et al. 2010). Coherent changes in cell structure have also been observed along ecological gradients. Cell numbers, latewood radial cell diameter, cell wall thickness, and wood density have been observed to decrease with increasing latitude (Wang et al. 2002; St-Germain and Krause 2008), and latewood density has been observed to decrease with elevation (Splechtna et al. 2000).

Because trees growing in Mediterranean continental climates are subjected to limitation from both climatic factors, namely cold temperatures in winter and drought stress in summer (Terradas and Savé 1992; Garcia-Plazaola et al. 1997), studying whether their anatomical structure is reflecting the environmental limiting conditions is highly interesting. Juniperus thurifera L. is a continental Mediterranean endemic conifer species forming distinct annual rings with very thin latewood (DeSoto 2010). This species can be found in the more cool, humid northwestern and central parts of Spain, as well as in the warm, dry regions of the eastern Iberian Peninsula (Amaral-Franco 1986). Previous dendroclimatic studies in central Spain and the French Pyrenees have shown that secondary growth of $J$. thurifera is mainly controlled by winter precipitation, spring temperature, and summer water stress (Bertaudière et al. 1999; Rozas et al. 2009).

In this study, we aim to explore the potential of cell anatomical features from the Mediterranean area to encode the information related to water availability. Here, we compared two groups of Mediterranean J. thurifera trees growing under differing water conditions with the aim (i) to recognize intraannual wood cell dimension patterns, (ii) to assess whether ring width and cell anatomical responses differ between wet and dry climates, and (iii) to verify if these differences can be used to link intra-annual patterns of cell anatomical features to seasonal climatic conditions.

\section{Material and methods}

\section{Study site, sampled trees, and tree-ring analyses}

Wood samples were collected from $J$. thurifera trees growing at two sites located at the eastern and western boundaries of the species distribution area (Fig. 1). Located in northwestern Spain near Palencia, the Peña Lampa site (LA; $42^{\circ} 50^{\prime} 31^{\prime \prime} \mathrm{N}, 4^{\circ} 51^{\prime} 36^{\prime \prime} \mathrm{W} ; 1187 \mathrm{~m}$ above sea level (a.s.l.)) encompasses the coolest, most humid region of its distribution. In contrast, the Santa Engracia site (SA; 41 $46^{\prime} 35^{\prime \prime} \mathrm{N}$, $0^{\circ} 32^{\prime} 29^{\prime \prime} \mathrm{W}$; $530 \mathrm{~m}$ a.s.l.) near Zaragoza in northeastern Spain is located in the warmest, driest part of the distribution range. At the LA site, J. thurifera constitutes a relict and dense population with scattered Quercus ilex L. At the
SA site, J. thurifera forms a coetaneous stand, after crops abandonment, intermingled with Pinus halepensis Mill. The sites are about $350 \mathrm{~km}$ apart. The soil at both sites is calcium rich.

In total, 40 dominant, healthy, mature trees (10 females and 10 males in each site) were randomly sampled. Sizes of the trees sampled between sites were comparable. Trees in LA were, on average, $6.1 \mathrm{~m}$ in height (standard deviation of \pm 1.5$)$ and showed a diameter at breast height $(\mathrm{DBH})$ of $20.7 \mathrm{~cm}( \pm 6.2)$. SA trees averaged $5.7 \mathrm{~m}$ in height $( \pm 0.6)$ and $18.9 \mathrm{~cm}$ in DBH $( \pm 3.7)$. Trees in LA were, on average, 95 years old $( \pm 18.8)$, and SA trees averaged 77 years $( \pm 20.9)$.

Two $5 \mathrm{~mm}$ diameter cores were extracted from each tree at stem breast height and perpendicular to the slope direction. Cores were glued on wooden mounts and polished for ring width measurement. Tree rings were measured to a resolution of $0.001 \mathrm{~mm}$ using a Velmex sliding-stage micrometer (Bloomfield, New York, USA), and visual cross-dating was verified using COFECHA (Grissino-Mayer 2001).

Climate-growth relationships were established by computing Pearson's correlations between the ring-width site chronologies and the monthly average temperature and total monthly precipitation. The chronologies were built by averaging the age-detrended time series. The age trend was removed by first applying a negative exponential function and then a 64-year cubic smoothing spline. Climatic data were obtained for the $0.5^{\circ}$ grids of the TS 3.0 data set (Climate Research Unit (CRU) 2008) closest to the tree sites for the period from 1951 to 2000 (50 years).

\section{Wood anatomical measurements}

The analysis of tracheid anatomical measurements has been performed on four specific annual rings (1979, 1986, 1991, 1996) from a set of tree cores with ring-width series that were highly intercorrelated with the mean chronology of the corresponding site $(r>0.5)$, i.e., those trees that better represent the common growth of the stand. We selected these four years on the basis of their climatic conditions: 1979 and 1996 displayed a precipitation maximum in winter, and 1986 and 1991 displayed a precipitation minimum in summer. In total, 13 series from eight trees for LA and 10 series from six trees for SA were selected, for a total of 92 annual rings. Comparisons of age and size of selected trees between the sites were not significantly different (age, $t_{12}=0.34$; diameter, $t_{12}=-1.55$; height, $t_{12}=1.56 ; P>0.05$ ), and sexes were equally distributed within the sites to control the individual effects.

To perform cell anatomical surveys using digital images of the wood core cross section, the core surface was prepared using a core microtome (Gärtner and Nievergelt 2010). The contrast between the tracheid lumina and the cell wall was improved by staining the wood surface with black printer ink (Canon Cartridge BCI-6BK, Canon Inc., Japan). Images of ring cross sections (RGB, color 24 bit) were captured using a digital video camera (ColorView III, Soft Imaging System, Germany) connected to a transmitted light microscope (Olympus BX41, Japan) with a $20 \times$ objective (image resolution: $0.17 \mu \mathrm{m} / \mathrm{pixel})$. Because the field of view through the objective was not large enough to cover the entire annual ring width, adjacent images from the same annual ring were 
Fig. 1. (a) Distribution area of Juniperus thurifera (shaded regions) in the Iberian Peninsula, locations of Peña Lampa (LA) and Santa Engracia (SA) sites (solid circles), and derived climate diagrams including mean monthly temperatures and total monthly precipitation. Numbers are mean annual temperature (range) and total annual precipitation. (b) Precipitation (solid line), potential evapotranspiration (PET, broken line), and water balance (WB, dotted line). Climate parameters were calculated over the period 1951-2000 obtained from the data set of the corresponding $0.5^{\circ}$ grid. Months are represented by their first letter.

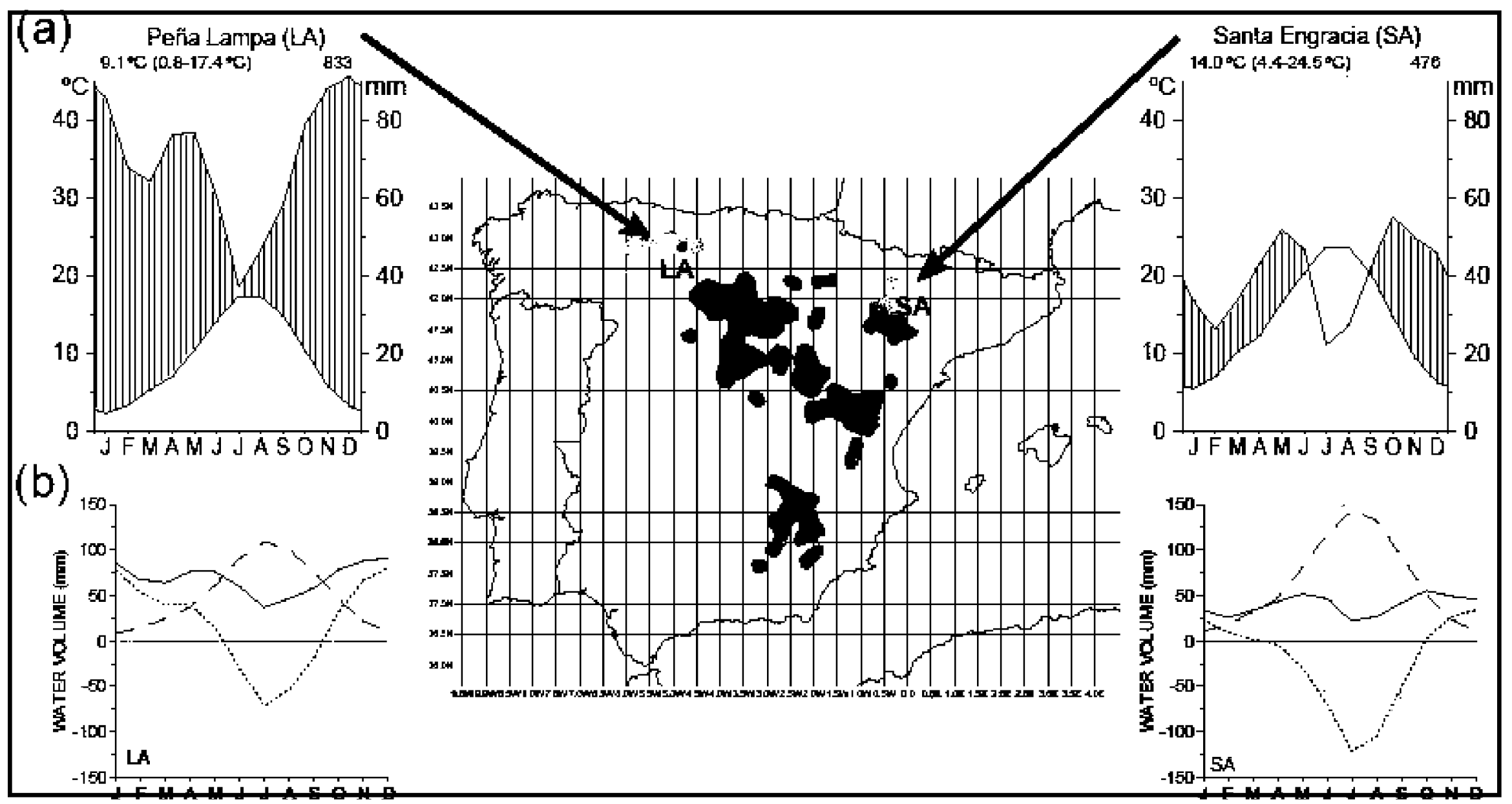


Fig. 2. Procedure for the cell anatomical measurements. (a) Image of an analyzed cross section with indication of the radial files (arrows lines) selected for the measurements. (b) Intensity values of a single line along a radial file (line profile in grey) and smoothing line in black. The horizontal grey line indicates the measure (in pixels) for each double cell wall thickness (light grey) or lumen diameter (dark grey) at 50 grey value as an standard value. (c) Schema indicating how the measured anatomical variables have been calculated. LD, radial lumen diameter; DWT, double cell wall thickness; CWT, cell wall thickness; TD, tracheid diameter.

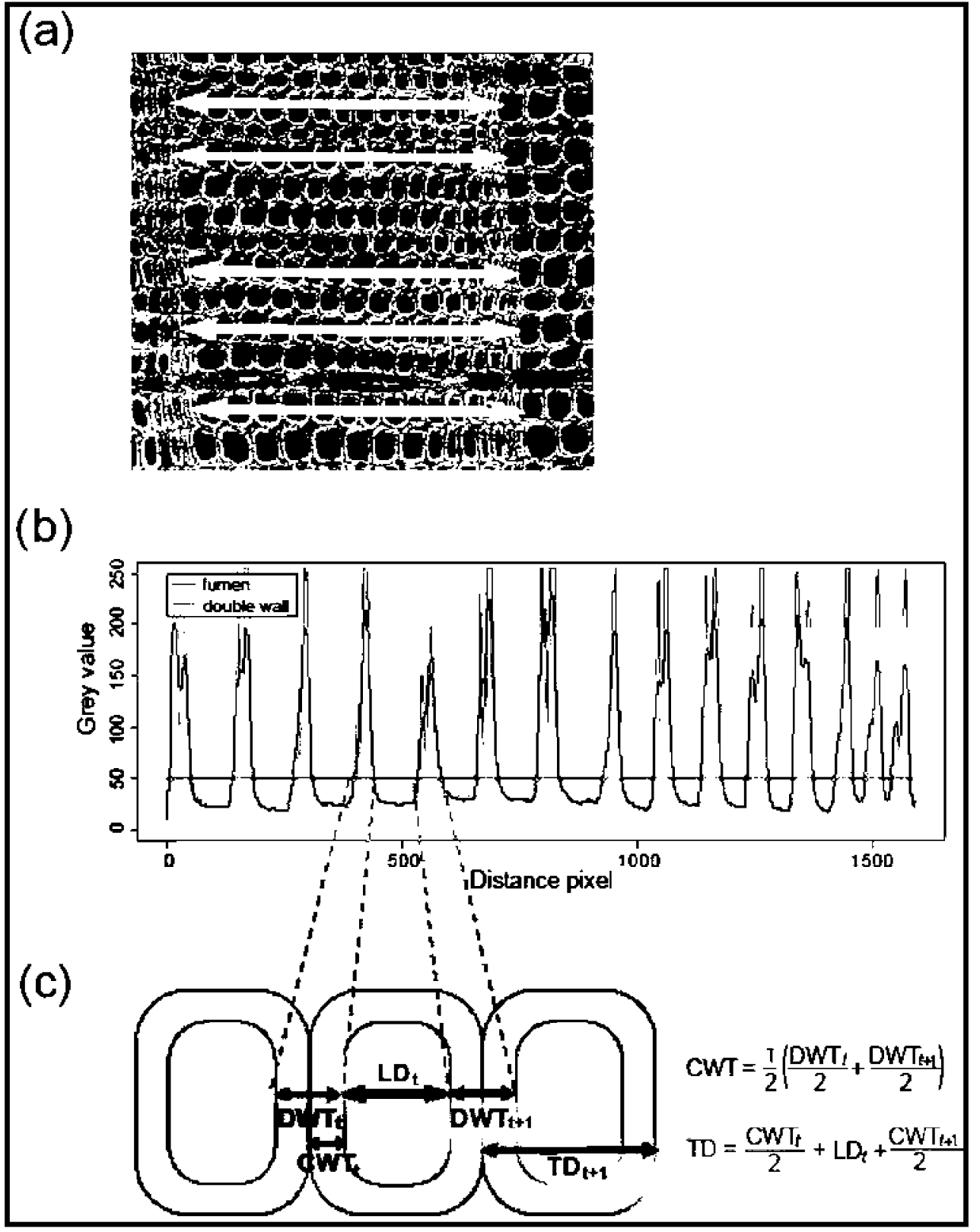

merged using the photo-stitching program PTgui. An example of a captured image is shown in Fig. $2 a$.

For each selected ring, the radial lumen diameter (LD) and the radial cell wall thickness (CWT) were measured along five tracheid files using the "plot profile" function of the image analysis program Image J (version $1.40 \mathrm{~g}$; Abramoff et al. 2004), which was used to discriminate between tracheid cell walls and cell lumina according to the variation of the grey value along a line passing trough a tracheid radial file (Fig. 2b). Tracheid files showing the tangentially largest cells were selected for measurement to consider only tracheids that were cut close to the middle of their longitudinal length. The radial tracheid diameter (TD) and the ratio of radial lumen diameter to radial cell wall thickness (LD/CWT) were then calculated (Fig. 2c). Cell anatomical data per file were transformed in a tracheidogram, i.e., a curve showing variations in cell parameters as a function of the cell position within an annual ring, using the procedure described by Vaganov (1990). This method normalizes the varying number of cells between radial files and annual rings to a fixed value. It is then possible to compare cells built in the same part of the season and also in an annual ring with a different number of cells. Tracheidograms were based on a normalized number of 23 cells ( 20 earlywood and three latewood) per ring. We normalized the number of cells per ring of the tracheidogram as the average of all the rings analyzed. Latewood tracheids 
were identified according to the Mork index (Denne 1988), i. e., when cell lumen is smaller than twice the cell wall. We have included a set of $\mathrm{R}$ functions to compute LD, CWT, $\mathrm{TD}$, and LD/CWT from the grey value line and the function to compute normalized tracheidograms in the new $\mathrm{R}$ package "tgram" (available from CRAN; http://cran.r-project.org; Fig. 2)

\section{Calculation of water stress and its relationship to tracheid anatomy}

Daily water balance (WB) over the year was estimated as the difference between the accumulated daily precipitation starting on 15 January and measured at the closest climatic stations of Velilla del Rio Carrión (LA) and Zaragoza Aula Dei (SA) provided by AEMet (Agencia Estatal de Meteorología) and the potential evapotranspiration estimated for each site as a function of the mean monthly temperatures and the geographical latitude (according to Thornthwaite 1948). Average water balances over 10-day periods from 1 March to 30 November ( 27 data points) were compared with the deviation of the observed tracheid diameter from the average tracheidogram of the four selected years of each site, which is considered an estimate of the site-specific "normal pattern" for cell size variation over the season. Timing of cell formation is estimated according to monitoring observation performed for the same species in similar environments (Camarero et al. 2010). The average tracheidogram has been fitted using a fourth-order polynomial function. Deviation was calculated as the difference between the observed tracheid diameter and the fitted function.

\section{Statistical analysis}

Generalized estimating equations (GEEs) where used to test the effect of years and sites on the wood anatomical features. GEEs are an extension of generalized linear models (GLMs) to model correlated data (Quinn and Keough 2002). GLMs provide a flexible way to model traits that do not satisfy the assumptions of a standard linear modelling and allow us to overcome the problems arising from the unbalanced and repeated structure of our data set. We specified a priori the covariance matrix (i.e., the structure of correlations between observations) as an autoregressive (AR1) structure. Models included year, sex, and site as fixed factors and their interactions; individuals $(n=14)$ were treated as the subject effect. We assumed a normal error distribution with an identity link function for mean $\mathrm{LD}, \mathrm{TD}$, and CWT and also for logarithmic transformation of earlywood, latewood, and total ring width. A Poisson error distribution with a log link function was assumed for the number of tracheids and for the latewood percentage. Least-squares means were obtained for each site, and the differences between them were tested pairwise by using the DIFF option in the LSMEANS statement. We fitted GLMs via restricted maximum-likelihood (REML) using the GEMMOD procedure of SAS (SAS Statistical package 9.1; SAS Institute Inc., Cary, North Carolina).

Tracheidogram parameters were analysed using multilevel models (MLMs) that fit linear models for longitudinal data (on individuals) over time (Omar et al. 1999; Quené and van der Bergh 2004). Longitudinal repeated measures, related to cell position in the ring, can be considered as hierarchical measures nested within a tracheidogram (Quinn and Keough
2002). This approach allows us to overcome the problems inherent to conventional repeated-measures ANOVA because it does not require the assumptions of homoscedasticity and sphericity and a complete set of data (Quené and van der Bergh 2004). We considered the anatomical features LD, CWT, TD, and LD/CWT as response variables and assumed a normal error distribution with an identity link function for all of them. Models included year, site, and position as explanatory fixed factors and all the possible two-way interactions among them. Tracheidograms ( $n=5-10$ ) were nested within individuals $(n=14)$ as a random effect to control the potential individual variability in the response (within individuals). We specified a priori as unstructured both levels of the covariance matrix (between individuals for the intercept and slopes and within individuals for the error). Differences of least-squares means were tested pairwise between sites within position by using the DIFF option in the LSMEANS statement. We fitted MLMs via restricted maximum likelihood (REML) using the MIXED procedure of SAS (Singer 1998; SAS Statistical package 9.1; SAS Institute Inc.).

\section{Results}

\section{Climatic conditions and water stress during the selected years}

Because of the higher yearly average temperature $\left(14.0^{\circ} \mathrm{C}\right)$ and lower precipitation sum $(476 \mathrm{~mm})$, the trees at the SA site suffered from longer and more intense periods of water stress than trees at the LA site $\left(9.1^{\circ} \mathrm{C}\right.$ and $833 \mathrm{~mm}$; Fig. 1). At SA, the water stress period, i.e., the period with negative water balance, reached a maximum of $-121 \mathrm{~mm}$ in June and lasted two months longer (April to September) than at LA (-71 mm, June to September).

For the selected climatic years, the years 1979 in LA and 1996 in SA were characterized by extremely wet winters ( $+130 \%$ and $113 \%$ in January to March) followed by a relatively dry spring and summer in comparison with the longterm average (1951-2000). In contrast, 1986 and 1991 were characterized by a dry winter, spring, and summer, especially at LA (Table 1). Climate parameters were calculated over the period 1951-2000 obtained from the CRU data set of the corresponding $0.5^{\circ}$ grid.

\section{Tree-ring growth and response to climate}

Trees at the stand in the dryer, warmer SA site showed larger ring widths (average 1951-2000 is $0.96 \mathrm{~mm}$ vs. $0.70 \mathrm{~mm})$ and higher mean sensitivity $\left(\mathrm{ms}_{x}=0.45\right.$ vs. 0.22$)$ than those at the wetter, cooler LA site, but both sites had similar common signals $\left(r_{\mathrm{bt}}=0.27\right.$ vs. 0.31 ; Fig. $3 a$ ). Climate-growth relationships indicated that trees at both sites responded similarly to summer conditions, with a positive response to total precipitation (July $r=0.28$ in SA vs. June $r=$ 0.40 in LA; $P<0.05$ ). In contrast, the climatic response to winter precipitation clearly differed between sites. The radial growth of trees at SA responded positively to precipitation (January $r=0.31 ; P<0.05$ ), whereas growth of LA trees responded negatively (November to February $r=-0.39$; March $r=-0.34 ; P<0.05$; Fig. $3 b$ ).

\section{Differences in cell numbers and sizes}

The mean ring widths of the analyzed years ranged from a 


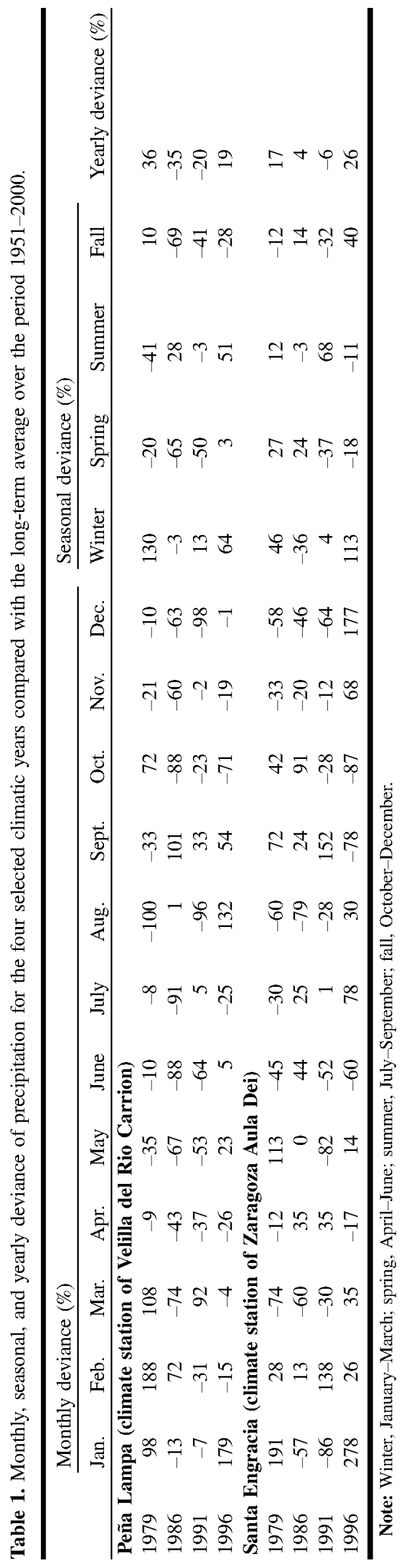

minimum of $275 \mu \mathrm{m}$ (15 tracheids 1991 in LA) to a maximum of $500 \mu \mathrm{m}$ (27 tracheids 1979 in SA) (Table 2). On average, $9 \%$ to $14 \%$ of xylem cells in the tree rings were classified as latewood. In the earlywood, the mean number of tracheids per radial file was lower at LA (12.86-21.34) than at SA (19.67-25.08) and was significantly different in 1986 and 1991 (Table 2). The mean TD of earlywood cells of like years was not statistically different between the sites ( $\chi^{2}$ test, $P>0.05$ ) and varied from 20.62 to $21.96 \mu \mathrm{m}$ for LA and from 20.25 to $22.44 \mu \mathrm{m}$ for SA. The mean CWT of earlywood cells varied from 2.78 to $2.94 \mu \mathrm{m}$ at LA and from 3.00 to $3.31 \mu \mathrm{m}$ at SA and differed significantly between sites in 1991 (Table 2). In the latewood, LA also displayed lower number of cells per radial file (1.74-1.89) and thinner CWT (2.63-2.78 $\mu \mathrm{m}$ ) than SA (respectively, 2.31-3.18 and 3.04-3.38 $\mu \mathrm{m}$ ). These differences were statistical different for all the years except for 1996. TD at SA $(9.02-10.50 \mu \mathrm{m})$ was larger than TD at LA $(8.46-9.08 \mu \mathrm{m})$; however, the difference was only significant in 1979 (Table 2; significant effects of the factors considered in the GEEs model are showed in Appendix Table A1).

Along the normalized tracheidogram, TD gradually decreased from 26 to $7 \mu \mathrm{m}$, whereas CWT varied around $3 \mu \mathrm{m}$, increasing slightly toward the latewood cells (Fig. 4). In general, SA showed more intra-annual variability, especially for the years 1979 and 1986. Comparisons between site tracheidograms showed statistical differences among the years and positions for all parameters ( $\chi^{2}$ test, $P<0.001$ ), and difference between the sites was marginally significant for $\mathrm{LD} / \mathrm{CWT}$ ( $P=0.064$; Table 3 ). Lower $\mathrm{LD} / \mathrm{CWT}$ values were observed for SA because of smaller LD and thicker CWT. (For significant effects of the individual factors sex and size in the extended MLMs, see Appendix A, Table A2.)

\section{Relationship between cell size and water stress}

During the selected years, trees at LA suffered less from water stress than those at SA. The water balance at LA is typically greater than $200 \mathrm{~mm}$; only in the summers of 1986 and 1991 did the water balance drop to less than zero. In contrast, water availability at SA was always limited and never reached values greater than $80 \mathrm{~mm}$. Drought stress in 1986 and 1991 was therefore more intense and persistent at SA than at LA (Fig. 5). A qualitative comparison of water balance patterns over the growing season and tracheid size deviation indicated some similarities between these two parameters. Despite the impossibility of synchronizing the two time series because of missing information about the timing of wood formation, it appeared that periods with a low water balance corresponded to smaller than average tracheids, and a positive change in the water balance after rewatering given by strong precipitation corresponded to an increase in tracheid size (Fig. 5). This relationship was especially manifest under dry conditions, i.e., for the dry SA site and for the drought summer years 1986 and 1991 of the mesic LA (Fig. 5).

\section{Discussion}

The climate of inland areas of the western Mediterranean Basin is characterized by cold, wet winters and hot, dry summers. Cambial activity can therefore be subjected to two 
Fig. 3. (a) Site chronologies and (b) growth responses to climate. LA, Peña Lampa; SA, Santa Engracia. Solid (LA) and dotted (SA) lines indicate mean radial width of all individuals sampled in the stands. Solid (LA) and open (SA) circles indicate the values relative of the trees selected for anatomical measurements. Vertical lines indicate the standard error. Arrows indicate the annual rings selected for cell anatomical analyses. Included data correspond to selected sampled trees for the period 1951-2000. Dendrochronological features for trees in the stand also included mean ring-width (MW) and standard deviation (SD) for the common interval, mean sensitivity ( $\mathrm{ms}_{x}$ ), and mean between-trees correlation $\left(r_{\mathrm{bt}}\right)$. Climate-growth relationships are calculated with monthly average temperature and sum precipitation over the period $1951-$ 2000 from the climatic stations of Zaragoza Aula Dei (SA) and Velilla del Rio Carrion (LA). Months are represented by their first letter.

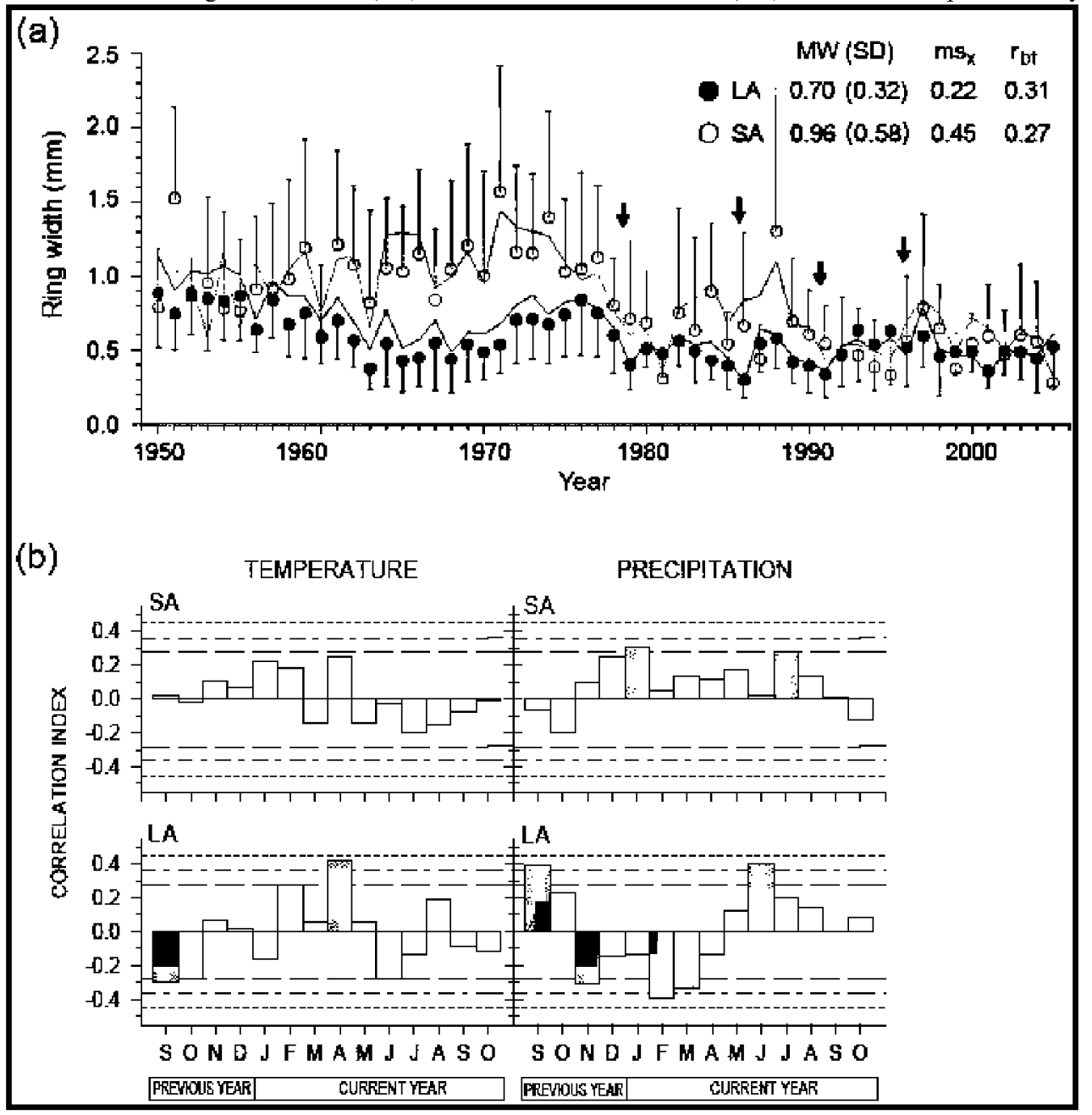

interruptions, one during the winter due to low temperatures and one during the summer triggered by water stress (Liphschitz and Lev-Yadun 1986; Cherubini et al. 2003). Therefore, depending on climate conditions of the year and on the autoecology of the species, differing seasonal patterns of secondary growth might occur (Camarero et al. 2010), which might also be able to affect the anatomical characteristics of the wooden cells formed during the growing season. Water stress is known to affect xylem growth directly and indirectly (Denne and Dodd 1981; Abe and Nakai 1999). In the early stage of water deficit, cell expansion is physically inhibited by the loss of cell turgor (Abe et al. 2003). As water deficit continues, stress affects the whole plant physiology, reducing or preventing cell metabolism and indirectly limiting growth (Larson 1963; Arend and Fromm 2007).

The $J$. thurifera trees analysed exhibited a growth response characteristic of Mediterranean trees, namely reduced growth in years characterized by relatively dry, warm summers. This confirms that cambial activity is controlled mainly by water availability during the growing season in Mediterranean regions (Cherubini et al. 2003). However, growth responses differed between $J$. thurifera sites for the late winter and early spring conditions. Precipitation inhibited growth at the wetter, colder LA site, likely because snow and cold conditions delayed the start of the growing season. By contrast, late winter and early spring precipitation at the dry, relatively mild SA site supplied the water needed for growth initiation. Therefore, growth at LA was affected by two climatic limiting factors: temperature at the beginning of the growing season and drought during the summer, whereas growth at SA was regulated primarily by water availability.

As for cell anatomical characteristics, the two sites exhibited similar cell anatomy, likely due to a strong genetic control of tracheid dimension (Willson et al. 2008). Although we observed some clear differences between the sites and among the climatic years, earlywood tracheids, which represented about $85 \%$ to $91 \%$ of the cells in the ring, showed lower $\mathrm{LD} / \mathrm{CWT}$ values at the drier site (SA) than at the more mesic 
Table 2. Least-squares mean and standard error (SE) of wood anatomical features of earlywood, latewood, and total ring cells for each studied year.

\begin{tabular}{|c|c|c|c|c|c|c|c|c|c|c|c|c|c|}
\hline \multirow[b]{2}{*}{ Wood features } & \multirow[b]{2}{*}{ Site } & \multicolumn{3}{|l|}{1979} & \multicolumn{3}{|l|}{1986} & \multicolumn{3}{|l|}{1991} & \multicolumn{3}{|l|}{1996} \\
\hline & & Mean & $\mathrm{SE}$ & $\chi^{2}$ & Mean & SE & $\chi^{2}$ & Mean & $\mathrm{SE}$ & $\chi^{2}$ & Mean & $\mathrm{SE}$ & $\chi^{2}$ \\
\hline \multicolumn{14}{|l|}{ Earlywood } \\
\hline \multirow[t]{2}{*}{ No. of cells } & LA & $21.34 \mathrm{ac}$ & 1.15 & 1.63 & $13.81 \mathrm{bc}$ & 1.17 & $8.81^{* * *}$ & $12.86 \mathrm{c}$ & 1.24 & $4.42^{*}$ & $17.77 \mathrm{ab}$ & 1.22 & 0.01 \\
\hline & SA & $25.08 \mathrm{a}$ & 1.17 & & $20.50 \mathrm{~b}$ & 1.09 & & $22.73 \mathrm{ab}$ & 1.29 & & $19.67 \mathrm{ab}$ & 1.34 & \\
\hline \multirow[t]{2}{*}{ RW } & LA & $413.43 \mathrm{ac}$ & 1.20 & 1.41 & $270.40 \mathrm{bc}$ & 1.22 & $6.39 *$ & $257.45 \mathrm{c}$ & 1.20 & 3.33 & $340.96 a b$ & 1.19 & 0.30 \\
\hline & SA & $470.11 \mathrm{a}$ & 1.23 & & $396.28 \mathrm{ab}$ & 1.10 & & $414.76 \mathrm{ab}$ & 1.29 & & $344.67 \mathrm{~b}$ & 1.36 & \\
\hline \multirow[t]{2}{*}{$\mathrm{LD}$} & LA & $15.63 \mathrm{a}$ & 0.60 & 0.78 & $14.99 \mathrm{a}$ & 0.71 & 1.04 & $16.16 \mathrm{~b}$ & 0.43 & $4.39 *$ & $16.14 \mathrm{ab}$ & 0.54 & 0.05 \\
\hline & SA & $14.99 \mathrm{a}$ & 0.42 & & $14.18 \mathrm{a}$ & 0.47 & & $14.48 \mathrm{a}$ & 0.35 & & $16.03 \mathrm{~b}$ & 0.76 & \\
\hline \multirow[t]{2}{*}{ CWT } & LA & 2.94 & 0.11 & 3.38 & 2.80 & 0.20 & 1.37 & 2.78 & 0.19 & $5.95 *$ & 2.91 & 0.17 & 1.51 \\
\hline & SA & $3.31 \mathrm{a}$ & 0.13 & & $3.00 \mathrm{~b}$ & 0.06 & & $3.08 \mathrm{ab}$ & 0.05 & & $3.23 \mathrm{~b}$ & 0.12 & \\
\hline \multirow[t]{2}{*}{ TD } & LA & 21.54 & 0.59 & 0.03 & 20.62 & 0.67 & 0.20 & 21.68 & 0.54 & 0.40 & 21.96 & 0.61 & 0.05 \\
\hline & SA & $21.61 \mathrm{a}$ & 0.37 & & $20.25 \mathrm{~b}$ & 0.39 & & $20.69 \mathrm{~b}$ & 0.31 & & $22.44 \mathrm{a}$ & 0.83 & \\
\hline \multicolumn{14}{|l|}{ Latewood } \\
\hline \multirow[t]{2}{*}{ No. of cells } & LA & 1.80 & 1.13 & $9.58 * *$ & 1.89 & 1.17 & $9.53^{* *}$ & 1.74 & 1.15 & $7.59^{* *}$ & 1.84 & 1.16 & 0.98 \\
\hline & SA & $2.55 \mathrm{a}$ & 1.10 & & $3.18 \mathrm{a}$ & 1.06 & & $2.79 \mathrm{a}$ & 1.08 & & $2.31 \mathrm{~b}$ & 1.13 & \\
\hline \multirow[t]{2}{*}{ RW } & LA & 13.42 & 1.14 & $15.42 * * *$ & 14.08 & 1.23 & $7.61 * *$ & 12.46 & 1.16 & $8.54 * *$ & 14.29 & 1.16 & 2.15 \\
\hline & SA & $23.12 \mathrm{a}$ & 1.14 & & $24.46 a$ & 1.07 & & $23.18 \mathrm{ab}$ & 1.12 & & $19.82 b$ & 1.14 & \\
\hline \multirow[t]{2}{*}{ LD } & LA & $3.27 \mathrm{a}$ & 0.16 & $5.80 *$ & $3.45 \mathrm{ab}$ & 0.22 & 3.48 & $3.19 \mathrm{ab}$ & 0.18 & 0.00 & $3.52 \mathrm{~b}$ & 0.21 & 0.03 \\
\hline & SA & $3.77 \mathrm{a}$ & 0.17 & & $2.92 \mathrm{~b}$ & 0.14 & & $3.19 b c$ & 0.16 & & $3.58 \mathrm{ac}$ & 0.28 & \\
\hline \multirow[t]{2}{*}{ CWT } & LA & $2.72 \mathrm{ab}$ & 0.14 & $18.54 * * *$ & $2.69 \mathrm{ab}$ & 0.15 & $6.39 *$ & $2.63 a$ & 0.13 & $7.22 * *$ & $2.78 \mathrm{~b}$ & 0.14 & 3.27 \\
\hline & SA & $3.38 \mathrm{a}$ & 0.10 & & $3.04 \mathrm{~b}$ & 0.03 & & $3.08 \mathrm{~b}$ & 0.10 & & $3.09 \mathrm{~b}$ & 0.11 & \\
\hline \multirow[t]{2}{*}{ TD } & LA & 8.69 & 0.39 & $14.72 * * *$ & 8.84 & 0.50 & 0.23 & 8.46 & 0.36 & 3.52 & 9.08 & 0.42 & 1.37 \\
\hline & SA & $10.50 \mathrm{a}$ & 0.36 & & $9.02 \mathrm{~b}$ & 0.15 & & $9.35 b$ & 0.30 & & $9.75 \mathrm{ab}$ & 0.47 & \\
\hline \multicolumn{14}{|l|}{ Total ring cells } \\
\hline \multirow[t]{2}{*}{ No. of cells } & LA & $22.65 \mathrm{ac}$ & 1.14 & 2.12 & $15.66 \mathrm{bc}$ & 1.16 & $9.63^{* *}$ & $14.97 \mathrm{c}$ & 1.21 & $5.07 *$ & $19.91 \mathrm{ac}$ & 1.20 & 0.00 \\
\hline & SA & 27.34 & 1.15 & & 23.93 & 1.08 & & 25.93 & 1.25 & & 22.16 & 1.31 & \\
\hline \multirow[t]{2}{*}{ RW } & LA & $426.48 \mathrm{ac}$ & 1.18 & 1.78 & $288.40 \mathrm{bc}$ & 1.21 & $6.69 *$ & $275.49 \mathrm{c}$ & 1.18 & 4.15 & $360.66 \mathrm{ab}$ & 1.19 & 0.22 \\
\hline & $\mathrm{SA}$ & 500.38 & 1.20 & & 428.06 & 1.09 & & 450.51 & 1.27 & & 367.71 & 1.35 & \\
\hline \multirow[t]{2}{*}{ LD } & $\mathrm{LA}$ & 14.60 & 0.70 & 0.76 & 13.78 & 0.84 & 0.68 & 14.50 & 0.44 & 2.36 & 14.80 & 0.50 & 0.24 \\
\hline & SA & $13.76 \mathrm{a}$ & 0.60 & & $12.78 \mathrm{~b}$ & 0.42 & & $12.98 \mathrm{~b}$ & 0.56 & & $14.40 \mathrm{a}$ & 0.91 & \\
\hline \multirow[t]{2}{*}{ CWT } & LA & 2.92 & 0.11 & $4.67 *$ & 2.78 & 0.19 & 1.94 & 2.76 & 0.17 & $7.35 * *$ & 2.90 & 0.16 & 1.46 \\
\hline & SA & $3.32 \mathrm{a}$ & 0.13 & & $3.00 \mathrm{~b}$ & 0.05 & & $3.09 \mathrm{ab}$ & 0.05 & & $3.21 b$ & 0.11 & \\
\hline \multirow[t]{2}{*}{ TD } & LA & 20.42 & 0.67 & 0.02 & 19.32 & 0.74 & 0.04 & 20.04 & 0.53 & 0.10 & 20.66 & 0.58 & 0.01 \\
\hline & SA & $20.41 \mathrm{a}$ & 0.54 & & $18.76 \mathrm{~b}$ & 0.34 & & $19.17 b$ & 0.52 & & $20.84 \mathrm{a}$ & 1.07 & \\
\hline Latewood (\%) & LA & $9.69 \mathrm{ac}$ & 1.16 & 0.32 & $12.49 \mathrm{~b}$ & 1.16 & 0.00 & $12.30 \mathrm{ab}$ & 1.12 & 0.28 & $9.25 \mathrm{c}$ & 1.09 & $4.94^{*}$ \\
\hline & SA & $11.92 \mathrm{a}$ & 1.24 & & $13.60 \mathrm{ab}$ & 1.06 & & $12.93 \mathrm{~b}$ & 1.21 & & $13.69 \mathrm{ab}$ & 1.17 & \\
\hline
\end{tabular}

Note: Data refer to eight trees (13 radii) in Peña Lampa (LA) and six trees (10 radii) in Santa Engracia (SA). Five radial files of cells are measured for each ring (for a total of 460 files). Least-squares mean significant differences between sites are indicated with asterisks $\left(\chi^{2}\right.$ test; $\left.*, P<0.05 ; * *, P<0.01 ; * * *, P<0.001\right)$ and among years are indicated with different letters $\left(\chi^{2}\right.$ test; $\left.P<0.05\right)$. Values for ring width (RW), lumen diameter (LD), cell wall thickness (CWT), and tracheid diameter (TD) are expressed in micrometres. 
Fig. 4. Site tracheidograms for each anatomical variable and selected climatic year. TD, radial tracheid diameter; LD, radial lumen diameter; CWT, radial cell wall thickness; LD/CWT, ratio of lumen diameter to cell wall thickness. LA, Peña Lampa $(n=8)$; SA, Santa Engracia $(n=6)$. The number of cell per rings has been normalized to 20 in earlywood (EW) and three in latewood (LW). Symbols indicate the mean, and vertical bars indicate the standard deviation. Lines in the TD tracheidograms indicate the average tracheidogram (fourth-order polynomial fitting).

LA
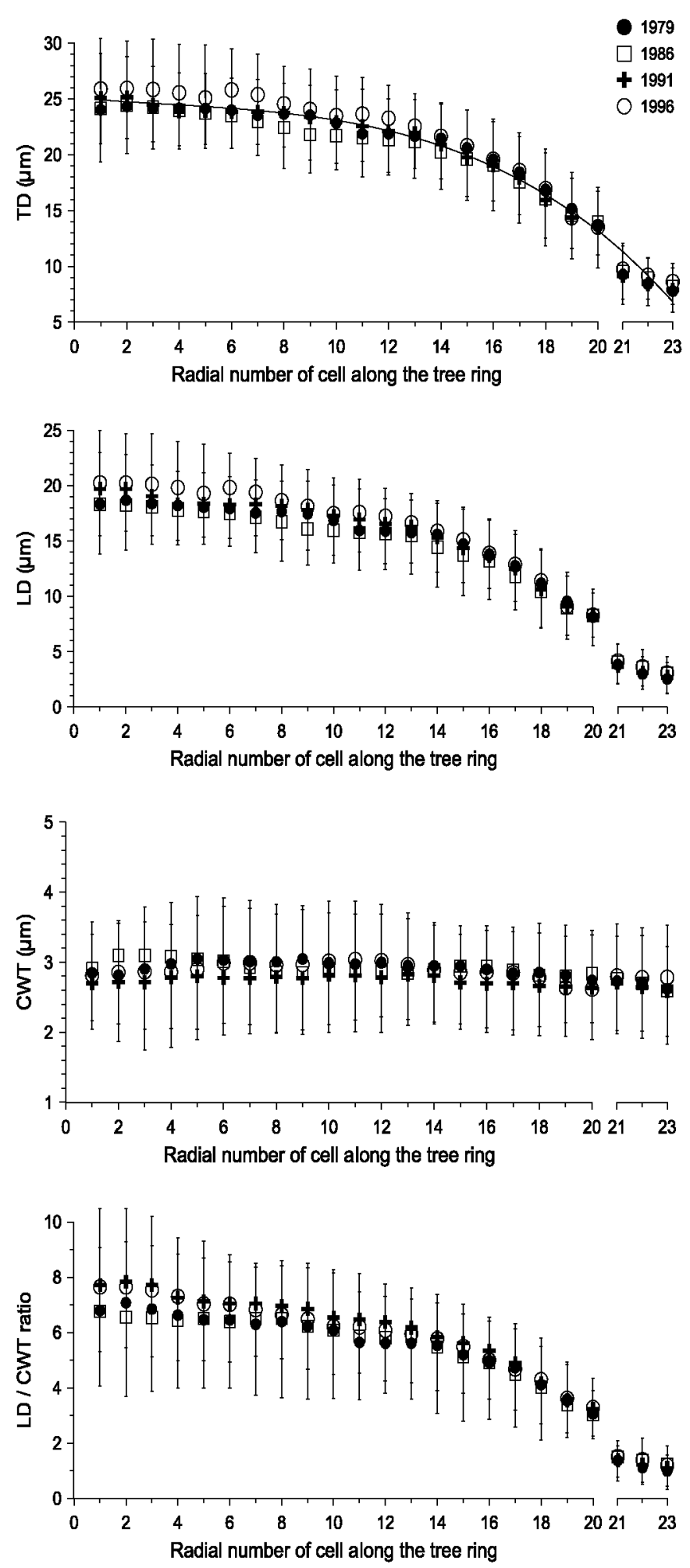

SA
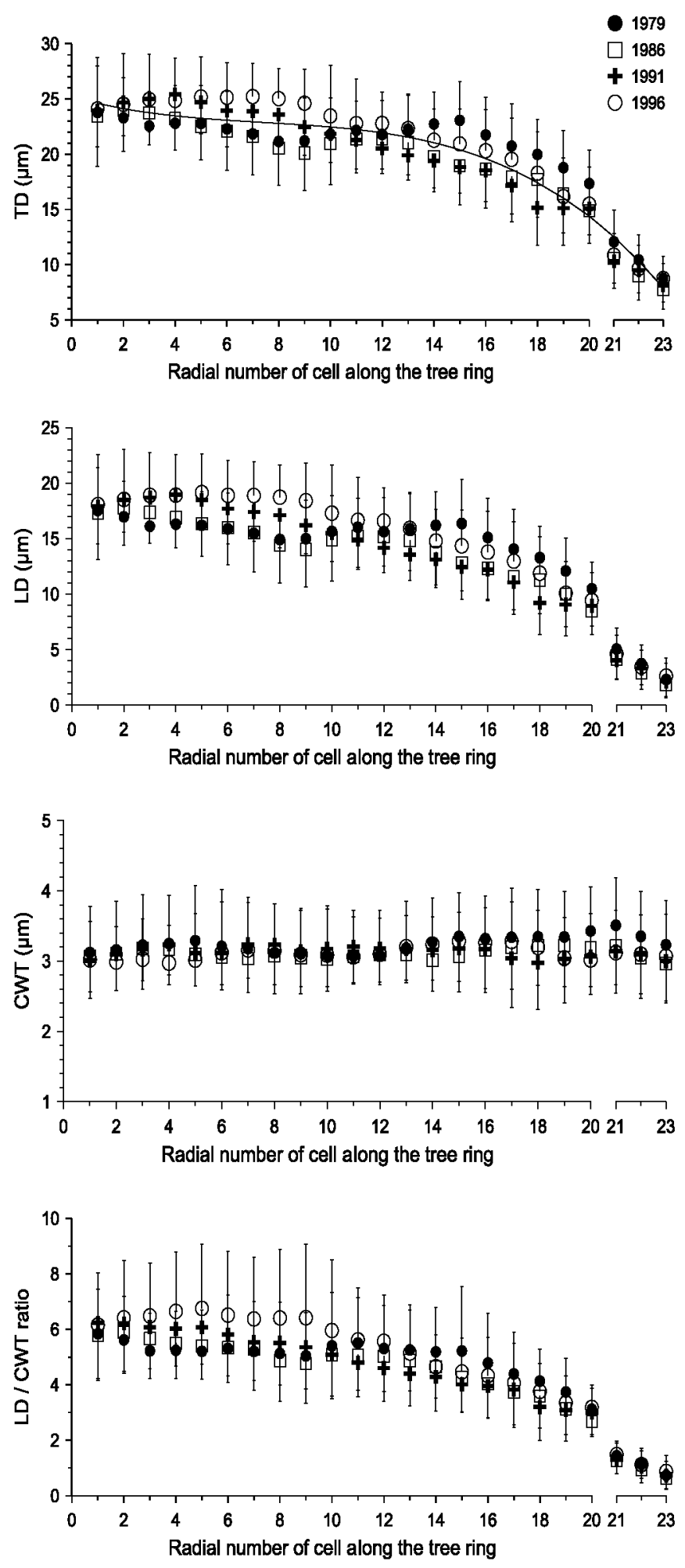
Table 3. Type III test conducted on the multilevel mixed model to test the effect of the fixed factors year, site, and cell position within the tracheidogram on the wood anatomical features.

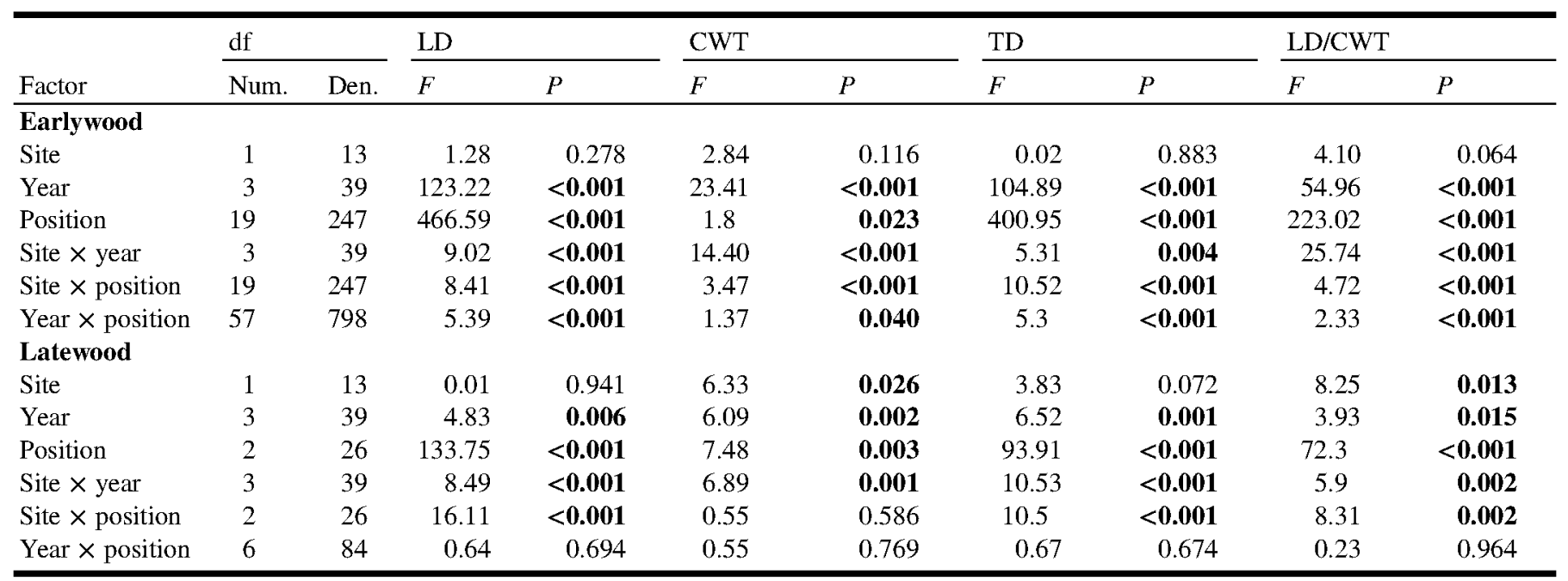

Note: LD, lumen diameter; CWT, cell wall thickness; TD, tracheid diameter; LD/CWT, ratio of lumen diameter to cell wall thickness. Data represent numerator (Num.) and denominator (Den.) of degrees of freedom (df), the $F$ statistic $(F)$, and $P$ value of significance $(P)$. Significant effects are in bold $(P<$ 0.05). $n=9600$ for earlywood and $n=1440$ for latewood, and number of radial files $=460$.

site (LA), whereas the intra-annual pattern of the wood cell anatomical characteristics was strongly affected by the within-year climatic conditions. All analyzed cell anatomical characteristics significantly differed among the years and positions within the rings. In general, we observed that intraannual unfavourable growing conditions such as water status reduction under drought conditions fostered the production of smaller, thicker tracheids, and vice versa. In particular, years with severe early summer drought (1986 and 1991) were characterized by smaller LD and thicker CWT. In addition, thicker CWT in the SA site occurred for the latewood tracheids of the years with drier conditions in fall (1979, 1986 and 1991; Tables 1, 2). Although the differences observed cannot be uniquely attributed to the differing responses to water availability (e.g., genotype, age, and stand structure are also site-specific), the observed results reinforce observations made for other species (Jenkings 1974; Nicholls and Waring 1977; Sheriff and Whitehead 1984). They are also consistent with the assumption that smaller, thicker cells are a safety adjustement against drought cavitation for conifers in limiting conditions (Cochard 1992; Willson and Jackson 2006; Eilmann et al. 2009).

Cell division in the SA dry site might occur in pulses depending on rainfall events (Camarero et al. 2010) and be oriented towards producing new larger sized tracheids needed to guarantee water transport. These results support previous interpretations of the occurrence of intra-annual density fluctuations, through unusual cell anatomical pattern within the ring, observed in Mediterranean tree species that have been related to variability in the seasonal amount and distribution of precipitation (Rigling et al. 2001; Masiokas and Villalba 2004; Campelo et al. 2007a, 2007b; De Luis et al. 2007; Rossi et al. 2009).

Differences were also observed in the number of tracheids, which was lower in LA $(\sim 18)$ than in SA $(\sim 25)$ in both of the dry years, 1986 and 1991. Large cell numbers and, subsequently, wider ring width, particularly in latewood, may re- sult as a direct consequence of a longer period of cambial activity (Camarero et al. 2010) or as a mechanism to preserve enough conductive area to overcome the consequences of tracheid cavitation; albeit the latter strategy should be further explored in the future.

This set of results confirms that the course of the seasonal climatic conditions is reflected in the intra-annual pattern of cell anatomical features. Although this study cannot directly link water balance to cell size because of the lack of timing of xylogenesis and in situ water stress measurements, there are, however, strong indications that these deviations in cell anatomical characteristics from the "regular pattern" can be an indicator of the tree water status over the growing season. In particular, for the dry site (SA) where growth was strongly limited by water stress, we observed very similar intra-annual patterns of water balance and cell size (Fig. 5). Similar behaviour is observable also for the more mesic site (LA); however, this relationship appears to be weaker and limited only to the years characterized by strong summer stress such as 1986 and 1991. Therefore we suggest that if drought is the main limiting factor over the whole growing season, deviation from average tracheidogram might be a function of water availability, as it has been previously described for other physiological activities in arid environments (Huxman et al. 2004).

In conclusion, the results obtained from this explorative study indicated that differences in cell anatomical characteristics between the dry and mesic sites of $J$. thurifera reflected site-specific adjustments, but also under dry conditions, there was a strong influence of the seasonal water availability on the intra-annual anatomical cell pattern. Specifically, those periods characterized by dry conditions seemed to promote the formation of smaller, thicker cells, and vice versa. Thus, through correct site selection, there is potential for using series of intra-annual wood anatomical features, particularly earlywood series, to retrospectively relate to the seasonal climatic pattern. 
Fig. 5. Relationships between deviation from average site tracheidogram of tracheid diameter (solid circles) and water balance (line) for each selected climatic year. LA, Peña Lampa (climate station of Velilla del Rio Carrion); SA, Santa Engracia (climate station of Zaragoza Aula Dei). Broken line indicates the average site tracheidogram. Solid line indicates decade of water balance starting from March to the end of November for every year and site. indicate decade of water balance starting from March to the end of November for every year and site. Xylogenesis timing in the figure is in accordance with that of a previous study with this species under similar conditions in the Iberian Penninsula (Camarero et al. 2010). Timing of earlywood is from April to July and timing of latewood formation is from September to October.

LA

SA
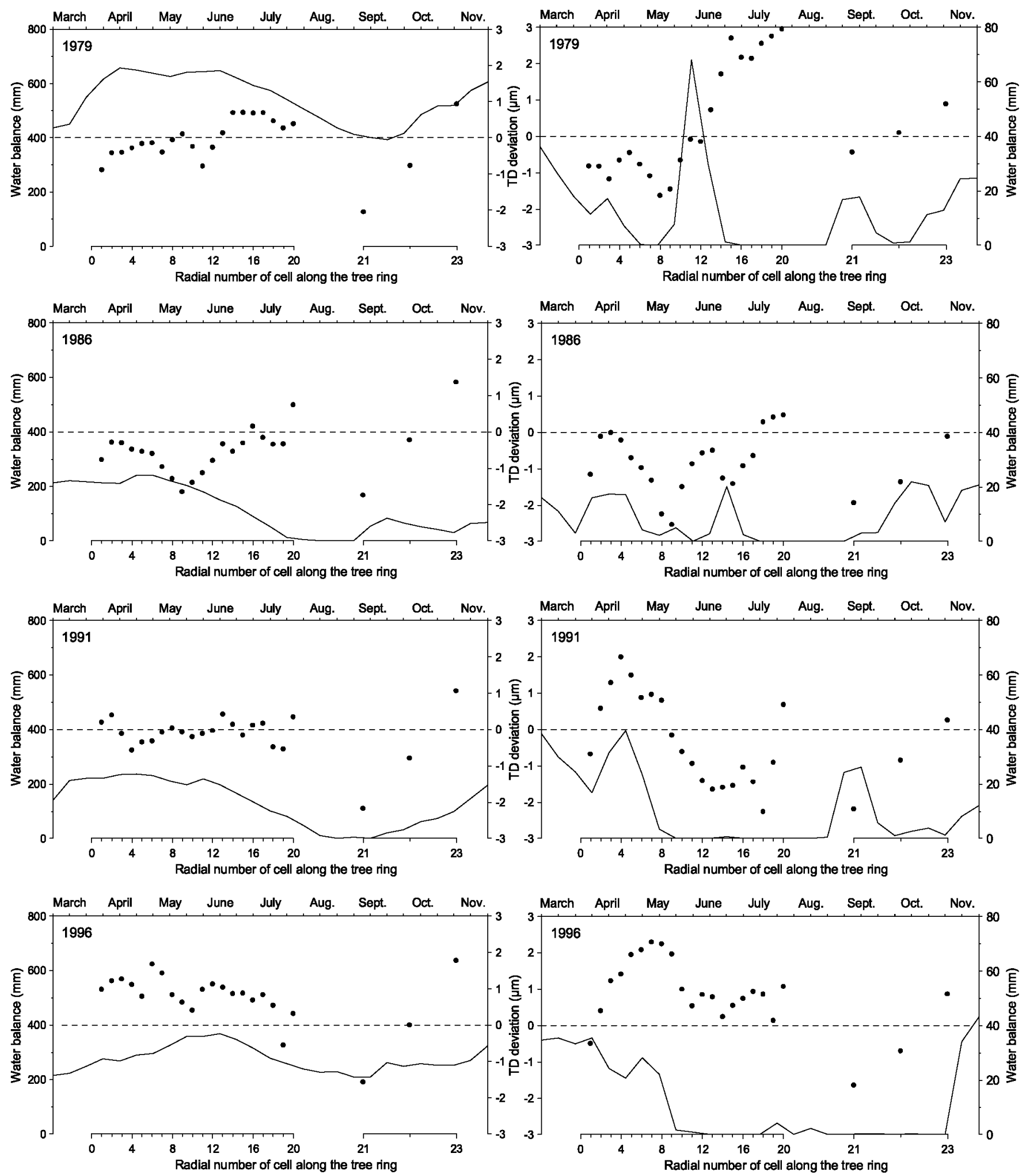


\section{Acknowledgements}

We thank H. Gärtner and F. Schweingruber for their advice about the laboratory work, J.M. Olano, V. Rozas, and R. Torices for their valuable suggestions on the manuscript, and E. Gleeson for her help in text editing. Climatic data were kindly provided by the Spanish Agencia Estatal de Meteorología (AEMet). SA site cores were contributed by J.J. Camarero, J.M. Olano, and A. Parras. At the LA site, V. Rozas, C. Torices, and R. Torices assisted in fieldwork. D. García-Gonzalez and O. Vallejo provided access to Peña Lampa. Junta de Castilla y León partially supported this research (project VA069A07). L. DeSoto was supported by a fellowship from Junta de Castilla y León and a short-stay fellowship from Valladolid University at the WSL Swiss Federal Research Institute.

\section{References}

Abe, H., and Nakai, T. 1999. Effect of the water status within a tree on tracheid morphogenesis in Cryptomeria japonica D. Don. Trees (Ber1.), 14(3): 124-129.

- Abe, H., Nakai, T., Utsumi, Y., and Kagawa, A. 2003. Temporal water deficit and wood formation in Cryptomeria japonica. Tree Physiol. 23(12): 859-863. PMID:12865252.

Abramoff, M.D., Magelhaes, P.J., and Ram, S.I. 2004. Image processing with ImageJ. Biophotonics International, 11(7): 36-42.

Amaral-Franco, J. 1986. Juniperus. In Flora Ibérica. Edited by S. Castroviejo, M. Laínz, G. López-González, P. Montserrat, F. Muñoz-Garmendia, J. Paiva, and L. Villar. Real Jardín Botánico, C.S.I.C., Madrid, Spain. pp. 181-188.

Antonova, G.F., and Stasova, V.V. 1993. Effects of environmental factors on wood formation in Scots pine stems. Trees (Berl.), 7(4): 214-219.

Antonova, G.F., and Stasova, V.V. 1997. Effects of environmental factors on wood formation in larch (Larix sibirica Ldb.) stems. Trees (Berl.), 11(8): 462-468.

Arend, M., and Fromm, J. 2007. Seasonal change in the drought response of wood cell development in poplar. Tree Physiol. 27(7): 985-992. PMID:17403651.

-Bertaudière, V., Montès, N., Gauquelin, T., and Édouard, J.L. 1999. Dendroécologie du genévrier thurifére (Juniperus thurifera L.): exemple de la thuriféraie de la montagne de Rié (Pyrénées, France). Ann. For. Sci. 56(8): 685-697. doi:10.1051/ forest: 19990806 .

- Camarero, J.J., Olano, J.M., and Parras, A. 2010. Plastic bimodal xylogenesis in conifers from continental Mediterranean climates. New Phytol. 185(2): 471-480. doi:10.1111/j.1469-8137.2009. 03073.x. PMID:19895415.

-Campelo, F., Gutierrez, E., Ribas, M., Nabais, C., and Freitas, H. 2007a. Relationships between climate and double rings in Quercus ilex from northeast Spain. Can. J. For. Res. 37(10): 1915-1923. doi:10.1139/X07-050.

-Campelo, F., Nabais, C., Freitas, H., and Gutierrez, E. $2007 \mathrm{~b}$. Climatic significance of tree-ring width and intra-annual density fluctuations in Pinus pinea from a dry Mediterranean area in Portugal. Ann. For. Sci. 64(2): 229-238. doi:10.1051/ forest:2006107.

-Cherubini, P., Gartner, B.L., Tognetti, R., Bräker, O.U., Schoch, W., and Innes, J.L. 2003. Identification, measurement and interpretation of tree rings in woody species from Mediterranean climates. Biol. Rev. Camb. Philos. Soc. 78(1): 119-148. doi:10.1017/ S1464793102006000. PMID:12620063.

Climate Research Unit. 2008. CRU datasets - CRU TS time-series [online]. University of East Anglia Climate Research Unit (CRU). Available from the British Atmospheric Data Centre at http://badc.nerc.ac.uk/view/badc.nerc.ac.uk_ATOM_dataent_ 1256223773328276.

- Cochard, H. 1992. Vulnerability of several conifers to air embolism. Tree Physiol. 11(1): 73-83. PMID:14969968.

-Creber, G., and Chaloner, W. 1984. Influence of environmental factors on the wood structure of living and fossil trees. Bot. Rev. 50(4): 357-448. doi:10.1007/BF02862630.

-De Luis, M., Gričar, J., Čufar, K., and Raventós, J. 2007. Seasonal dynamics of wood formation in Pinus halepensis from dry and semi-arid ecosystems in Spain. IAWA J. 28(4): 389-404.

Denne, M.P. 1988. Definition of latewood according to Mork (1928). IAWA Bull. 10(1): 59-62.

Denne, M.P., and Dodd, R.S. 1981. The environmental control of xylem differentiation. In Xylem cell development. Edited by J.R. Barnett. Castle House Publications Ltd., Kent, UK. pp. 236-255.

DeSoto, L. 2010. Global change effect on the dioecious tree Juniperus thurifera in the Iberian Peninsula. Ph.D. thesis, Instituto Universitario de Investigación en Gestión Forestal Sostenible, University of Valladolid, Soria, Spain.

-Eilmann, B., Zweifel, R., Buchmann, N., Fonti, P., and Rigling, A. 2009. Drought induced adaptation of xylem in Scots pine and pubescent oak. Tree Physiol. 29(8): 1011-1020. doi:10.1093/ treephys/tpp035. PMID:19483185.

Fonti, P., Solomonoff, N., and García-González, I. 2007. Earlywood vessels of Castanea sativa record temperature before their formation. New Phytol. 173(3): 562-570. doi:10.1111/j.14698137.2006.01945.x. PMID:17244050.

-Fonti, P., von Arx, G., García-González, I., Eilmann, B., SassKlaassen, U., Gärtner, H., and Eckstein, D. 2010. Studying global change through investigation of the plastic responses of xylem anatomy in tree rings. New Phytol. 185(1): 42-53. doi:10.1111/j 1469-8137.2009.03030.x. PMID:19780986.

Fritts, H.C. 2001. Tree rings and climate. Blackburn Press, Caldwell, New Jersey.

-Gallé, A., Esper, J., Feller, U., Ribas-Carbo, M., and Fonti, P. 2010. Responses of wood anatomy and carbon isotope composition of Quercus pubescens saplings subjected to two consecutive years of summer drought. Ann. For. Sci. 67(8): 809. doi:10.1051/forest/ 2010045.

- Garcia-Plazaola, J.I., Faria, T., Abadia, J., Abadia, A., Chaves, M.M., and Pereira, J.S. 1997. Seasonal changes in xantophyll composition and photosynthesis of cork oak (Quercus suber L.) leaves under Mediterranean climate. J. Exp. Bot. 48(9): 1667-1674. doi:10.1093/jxb/48.9.1667.

-Gärtner, H., and Nievergelt, D. 2010. The core-microtome. A new tool for surface preparation on cores and time series analysis of varying cell parameters. Dendrochronologia, 28(2): 85-92. doi:10. 1016/j.dendro.2009.09.002.

-Gind1, W. 2001. Cell-wall lignin content related to tracheid dimensions in drought sensitive Austrian pine (Pinus nigra Arnold). IAWA J. 22(2): 113-120.

Grissino-Mayer, H.D. 2001. Evaluating crossdating accuracy: a manual and tutorial for the computer program COFECHA. TreeRing Res. 57(2): 205-221.

-Huxman, T.E., Snyder, K.A., Tissue, D., Leffler, A.J., Ogle, K., Pockman, W.T., Sandquist, D.R., Potts, D.L., and Schwinning, S. 2004. Precipitation pulses and carbon fluxes in semiarid and arid ecosystems. Oecologia, 141(2): 254-268. doi:10.1007/s00442004-1682-4. PMID:15338414.

Jenkings, P.A. 1974. Influence of temperature change on wood formation in Pinus radiata grown in controlled environments. N.Z. J. Bot. 13: 579-592. 
Larson, P.R. 1963. The indirect effect of drought on tracheid diameter in red pine. For. Sci. 9(1): 52-62.

Liphschitz, N., and Lev-Yadun, S. 1986. Cambial activity in evergreen and seasonal dimorphics around the Mediterranean. IAWA Bull. 7(2): 145-153.

-Masiokas, M., and Villalba, R. 2004. Climatic significance of intraannual bands in the wood of Nothofagus pumilio in southern Patagonia. Trees (Berl.), 18(6): 696-704. doi:10.1007/s00468004-0355-6.

Nicholls, J.W.P., and Waring, H.D. 1977. The effect of environmental factors on wood characteristics. IV. Irrigation and partial droughting of Pinus radiata. Silvae Genet. 26(2-3): 107-111.

- Omar, R.Z., Wright, E.M., Turner, R.M., and Thompson, S.G. 1999. Analysing repeated measurements data: a practical comparison of methods. Stat. Med. 18(13): 1587-1603. doi:10.1002/(SICI)10970258(19990715)18:13<1587::AID-SIM141>3.0.CO;2-Z. PMID: 10407231.

Oribe, Y., Funada, R., and Kubo, T. 2003. Relationships between cambial activity, cell differentiation and the localisation of starch in storage tissues around the cambium in locally heated stems of Abies sachalinensis (Schmidt) Masters. Trees (Berl.), 17(3): 185192.

- Panyushkina, I.P., Hughes, M.K., Vaganov, E.A., and Munro, M.A.R. 2003. Summer temperature in northeastern Siberia since 1642 reconstructed from tracheids dimensions and cell numbers of Larix cajanderi. Can. J. For. Res. 33(10): 1905-1914. doi:10.1139/x03109.

-Quené, H., and van der Bergh, H. 2004. On multi-level modeling of data from repeated measures designs: a tutorial. Speech Commun. 43(1-2): 103-121. doi:10.1016/j.specom.2004.02.004.

Quinn, G.P., and Keough, M.L. 2002. Experimental design and data analysis for biologists. Cambridge University Press, Cambridge, UK.

- Rigling, A., Waldner, P.O., Forster, T., Braker, O.U., and Pouttu, A. 2001. Ecological interpretation of tree-ring width and intra-annual density fluctuations in Pinus sylvestris on dry sites in the central Alps and Siberia. Can. J. For. Res. 31(1): 18-31. doi:10.1139/cjfr31-1-18.

- Rossi, S., Simard, S., Rathgeber, C.B.K., Deslauriers, A., and De Zan, C. 2009. Effects of a 20-day-long dry period on cambial and apical meristem growth in Abies balsamea seedlings. Trees (Ber1.), 23(1): 85-93. doi:10.1007/s00468-008-0257-0.

-Rozas, V., DeSoto, L., and Olano, J.M. 2009. Sex-specific, agedependent sensitivity of tree-ring growth to climate in the dioecious tree Juniperus thurifera. New Phytol. 182(3): 687697. doi:10.1111/j.1469-8137.2009.02770.x. PMID:19210720.

Schweingruber, F.H. 2007. Wood structure and environment. Series in Wood Science, Springer-Verlag, Berlin, Germany.

- Sheriff, D.W., and Whitehead, D. 1984. Photosynthesis and wood structure in Pinus radiata D. Don during dehydration and immediately after rewatering. Plant Cell Environ. 7(1): 53-62. doi:10.1111/j.1365-3040.1984.tb01200.x.
- Singer, J. 1998. Using SAS PROC MIXED to fit multilevel models, hierarchical models, and individual growth models. J. Educ. Behav. Stat. 23(4): 323-355.

-Splechtna, B.E., Dobrys, J., and Klinka, K. 2000. Tree-ring characteristics of subalpine fir (Abies lasiocarpa (Hook.) Nutt.) in relation to elevation and climatic fluctuations. Ann. For. Sci. 57(2): 89-100. doi:10.1051/forest:2000105.

-St-Germain, J.-L., and Krause, C. 2008. Latitudinal variation in treering and wood cell characteristics of Picea mariana across the continuous boreal forest in Quebec. Can. J. For. Res. 38(6): 13971405. doi:10.1139/X08-008.

Terradas, J., and Savé, R. 1992. The influence of summer and winter stress and water relationships on the distribution of Quercus ilex $\mathbf{L}$. Vegetatio, 90-100(1): 137-145. doi:10.1007/BF00118219.

- Thornthwaite, C.W. 1948. An approach toward a rational classification of climate. Geogr. Rev. 38(1): 55-94. doi:10.2307/210739.

-Uggla, C., Mellerowicz, E.J., and Sundberg, B. 1998. Indole-3-acetic acid controls cambial growth in Scots pine by positional signalling. Plant Physiol. 117(1): 113-121. doi:10.1104/pp.117. 1.113. PMID:9576780.

-Uggla, C., Magel, E., Moritz, T., and Sundberg, B. 2001. Function and dynamics of auxin and carbohydrates during earlywood/ latewood transition in Scots pine. Plant Physiol. 125(4): 20292039. doi:10.1104/pp.125.4.2029. PMID:11299382.

Vaganov, E.A. 1990. The tracheidogram method in tree-ring analysis and its application. In Methods of dendrochronology: applications in the environmental sciences. Edited by E.R. Cook and L.A. Kairiukstis. Kluwer Academic Publishers, Dordrecht, the Netherlands. pp. 63-76.

Vysotskaya, L.G., and Vaganov, E.A. 1989. Components of the variability of radial cell size in tree rings of conifers. IAWA Bull. 10(4): 417-428.

-Wang, L., Payette, S., and Bégin, Y. 2002. Relationships between anatomical and densitometric characteristics of black spruce and summer temperature at tree line in northern Québec. Can. J. For Res. 32(3): 477-486. doi:10.1139/x01-208.

-Willson, C.J., and Jackson, R.B. 2006. Xylem cavitation caused by drought and freezing stress in four co-occurring Juniperus species. Physiol. Plant. 127(3): 374-382. doi:10.1111/j.1399-3054.2006. 00644.x.

-Willson, C.J., Manos, P.S., and Jackson, R.B. 2008. Hydraulic traits are influenced by phylogenetic history in the drought-resistant, invasive genus Juniperus (Cupressaceae). Am. J. Bot. 95(3): 299 314. doi:10.3732/ajb.95.3.299.

-Wimmer, R. 2002. Wood anatomical features in tree-rings as indicators of environmental change. Dendrochronologia, 20(1-2): 21-36. doi:10.1078/1125-7865-00005.

\section{Appendix A}

Tables A1 and A2 follow. 


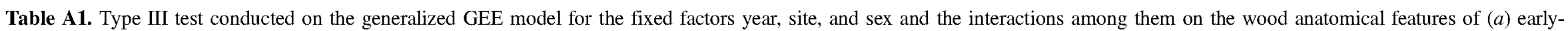
wood $(\mathrm{EW})$ and $(b)$ latewood (LW).

\begin{tabular}{|c|c|c|c|c|c|c|c|c|c|c|c|c|c|}
\hline \multirow[b]{2}{*}{ Effect } & \multirow[b]{2}{*}{$\mathrm{df}$} & \multicolumn{2}{|l|}{ LD } & \multicolumn{2}{|l|}{ CWT } & \multicolumn{2}{|l|}{$\mathrm{TD}$} & \multicolumn{2}{|l|}{$N$} & \multicolumn{2}{|c|}{ Log Width } & \multicolumn{2}{|l|}{$\% \mathrm{LW}$} \\
\hline & & $X^{2}$ & $P$ & $X^{2}$ & $P$ & $X^{2}$ & $P$ & $X^{2}$ & $P$ & $X^{2}$ & $P$ & $X^{2}$ & $P$ \\
\hline \multicolumn{14}{|l|}{ (a) $\mathrm{EW}$} \\
\hline Year & 3 & 5.22 & 0.156 & 5.13 & 0.162 & 7.87 & 0.049 & 6.28 & 0.099 & 4.86 & 0.183 & 5.22 & 0.156 \\
\hline Site & 1 & 1.46 & 0.227 & 2.43 & 0.119 & 0.10 & 0.754 & 1.99 & 0.159 & 1.52 & 0.218 & 1.46 & 0.227 \\
\hline Sex & 1 & 0.03 & 0.862 & 0.44 & 0.505 & 0.29 & 0.593 & 0.11 & 0.744 & 0.05 & 0.819 & 0.03 & 0.862 \\
\hline Year $\times$ site & 3 & 4.98 & 0.173 & 1.94 & 0.585 & 7.12 & 0.068 & 5.32 & 0.150 & 4.04 & 0.257 & 4.98 & 0.173 \\
\hline Year $\times$ sex & 3 & 4.06 & 0.255 & 3.74 & 0.291 & 2.27 & 0.519 & 1.81 & 0.612 & 0.87 & 0.832 & 4.06 & 0.255 \\
\hline $\begin{array}{l}\text { Site } \times \text { sex } \\
\text { (b) } \mathbf{L W}\end{array}$ & 1 & 2.69 & 0.101 & 3.36 & 0.067 & 0.57 & 0.450 & 1.40 & 0.236 & 0.55 & 0.460 & 2.69 & 0.101 \\
\hline Year & 3 & 3.74 & 0.290 & 5.66 & 0.130 & 4.69 & 0.196 & 3.13 & 0.372 & 0.78 & 0.854 & 3.74 & 0.290 \\
\hline Site & 1 & 0.00 & 0.957 & 5.34 & 0.021 & 3.67 & 0.056 & 5.19 & 0.023 & 4.97 & 0.026 & 0.00 & 0.957 \\
\hline Sex & 1 & 0.35 & 0.553 & 0.98 & 0.323 & 0.25 & 0.619 & 0.00 & 0.976 & 0.01 & 0.941 & 0.35 & 0.553 \\
\hline Year $\times$ site & 3 & 6.57 & 0.087 & 4.56 & 0.207 & 5.51 & 0.138 & 4.97 & 0.174 & 3.95 & 0.267 & 6.57 & 0.087 \\
\hline Year $\times$ sex & 3 & 6.50 & 0.090 & 4.86 & 0.183 & 5.78 & 0.123 & 0.38 & 0.945 & 0.77 & 0.856 & 6.50 & 0.090 \\
\hline Site $\times$ sex & 1 & 0.10 & 0.754 & 0.42 & 0.516 & 0.34 & 0.558 & 1.51 & 0.219 & 1.49 & 0.223 & 0.10 & 0.754 \\
\hline Distribution & & Normal & & Normal & & Normal & & Poisson & & Normal & & Poisson & \\
\hline Link function & & Identity & & Identity & & Identity & & Log & & Identity & & $\log$ & \\
\hline No. of cases & & 460 & & 460 & & 460 & & 450 & & 450 & & 450 & \\
\hline
\end{tabular}

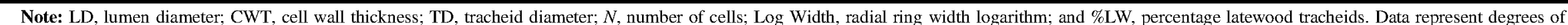
freedom $(\mathrm{df})$, the Chi-Square test $\left(\chi^{2}\right)$, and $P$ value of significance $(P)$. Significant effects are in bold $(P<0.05) . n=460$. 


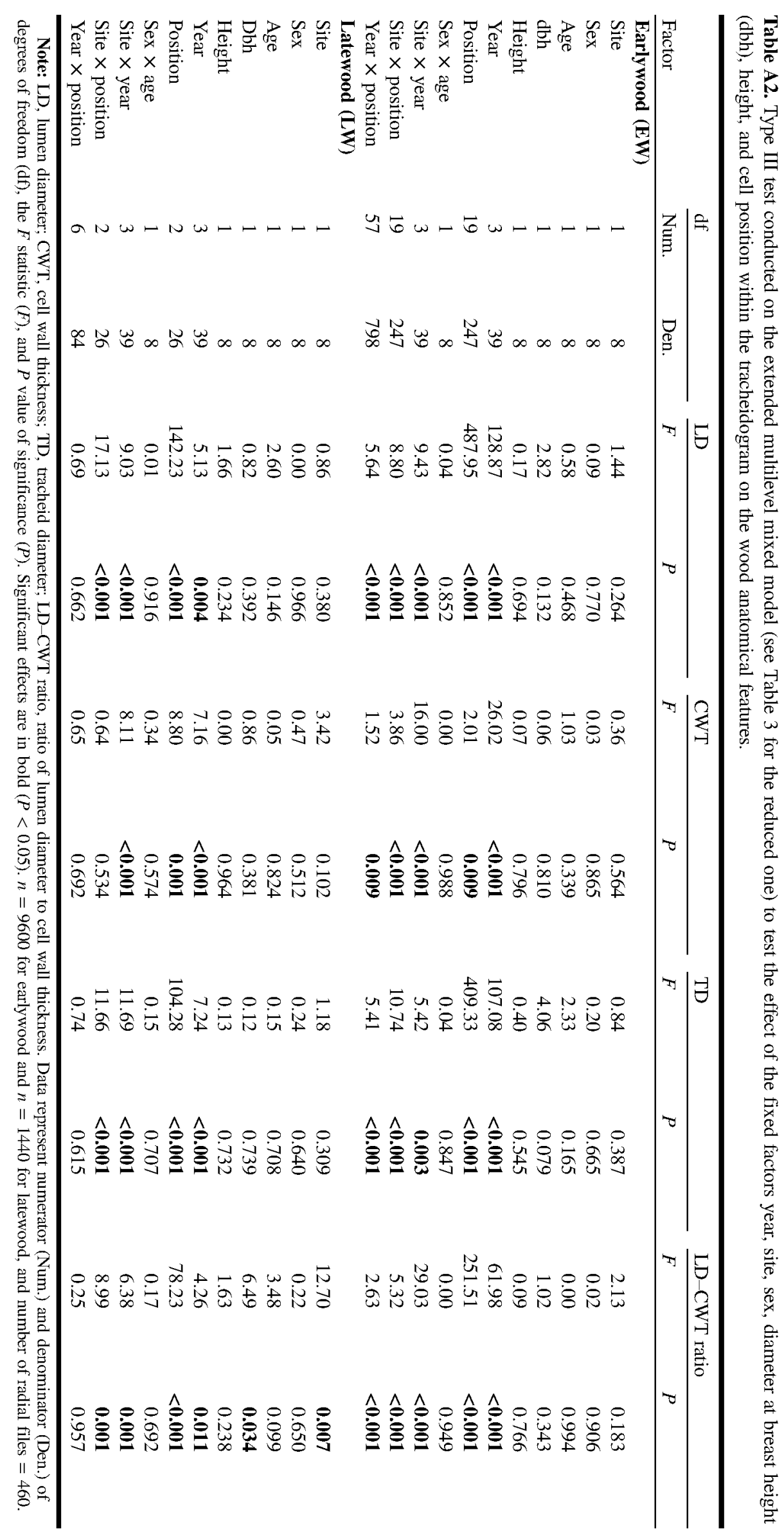

